\title{
Pharmacologic Effect of 5-Methoxytryptophol
}

\author{
Ahmet Özer Șehirli' (D, Gökçe Savtekin² (1) \\ 'Department of Pharmacology, Near East University School of Dentistry, Nicosia, Cyprus \\ 2Department of Oral and Maxillofacial Surgery, Near East University School of Dentistry, Nicosia, Cyprus
}

ORCID IDs of the authors: A.Ö.Ș. 0000-0002-5I75-9290; G.S. 0000-000I-8870-6603.

Cite this article as: Șehirli AÖ, Savtekin G. Pharmacologic Effect of 5-Methoxytryptophol. Cyprus J Med Sci 2018; 3(3): 189-92.

\begin{abstract}
5-methoxytryptophol (5-MTX) is an indolamine synthesized from the pineal gland hormones. This indolamine, synthesized from serotonin and melatonin, has been shown to be biologically active in different species. In particular, its activation is regulated by radiation stimuli such as sunlight. 5-methoxytryptophol-mediated receptors play a role in the regulation of cerebral artery contractility, intracarrhythmia, and the regulation of the renal function. It also shows immunomodulator, antioxidant, and anxiolytic properties with different mechanisms. To date, studies examining the mechanism of 5-MTX have been done, but these are insufficient to explain it. In our study, all of these studies were examined, and we aimed to explain the pharmacological and therapeutic effect of 5-MTX as a review. In particular, the fact that melatonin secreted in the dark and 5-MTX released in the light create a 24-hour protective effect will bring a new perspective to new studies. This will lead to the creation of a new clinical and scientific research, which will lay groundwork for the creation of alternative treatment regimens.
\end{abstract}

Keywords: 5-methoxytryptophol, melatonin, serotonin

\section{INTRODUCTION}

5-methoxytryptophol (5-MTX) is a hormone synthesized from the pineal gland hormones. This indolamine, synthesized from serotonin and melatonin, has been shown to be biologically active in amphibians, reptiles, fish, birds, and mammals and is physiologically regulated by radiation stimuli such as sunlight. Some researchers report that 5-MTX has a similar endocrine effect as melatonin and has a 24-hour circadian pattern in blood. This indolamine, unlike melatonin, is photoperiod dependent and oscillates in the daytime, whereas its levels in blood are inversely proportional at nighttime (I).

Circadian and "seasonal" rhythms of 5-MTX have been identified in studies on various vertebrate species and gastropods. For example, in a human study, the levels of 5-MTX were investigated between January and March, which is called the short photoperiod, and it was found to have higher concentrations during the day and lower concentrations during the night. As a matter of fact, during the summer months, 5-MTX was found in higher concentrations in plasma at night due to a high production related to the photoperiod, compared with the winter months. As a result, it was determined that the pineal gland is affected by photoperiods in the synthesis of 5-MTX (2).

\section{Synthesis}

There are two ways to synthesize 5-MTX.

The first way begins with the deamination of serotonin by oxidative monoamine oxidase (MAO). Serotonin is deaminated by MAO through the oxidation mechanism into the 5-hydroxyindole acetaldehyde. With the catalytic activation of the enzyme aldehyde reductase (AR), 5-hydroxyindole acetaldehyde is reduced down to 5-hydroxytryptophol. 5-hydroxytryptophol is methylated by the 5-hydroxyindole-O-methyltransferase enzyme to form 5-MTX (Figure I) (3).

Along with this method, 5-MTX is made from melatonin alongside another metabolic mechanism in the retina, kidney, and liver. Melatonin is converted to 5-methoxytryptamine by deacetylation. 5-methoxytryptamine then forms 5-methoxyindolacetic acid and 5-MTX through deamination (Figure 2) (4). 

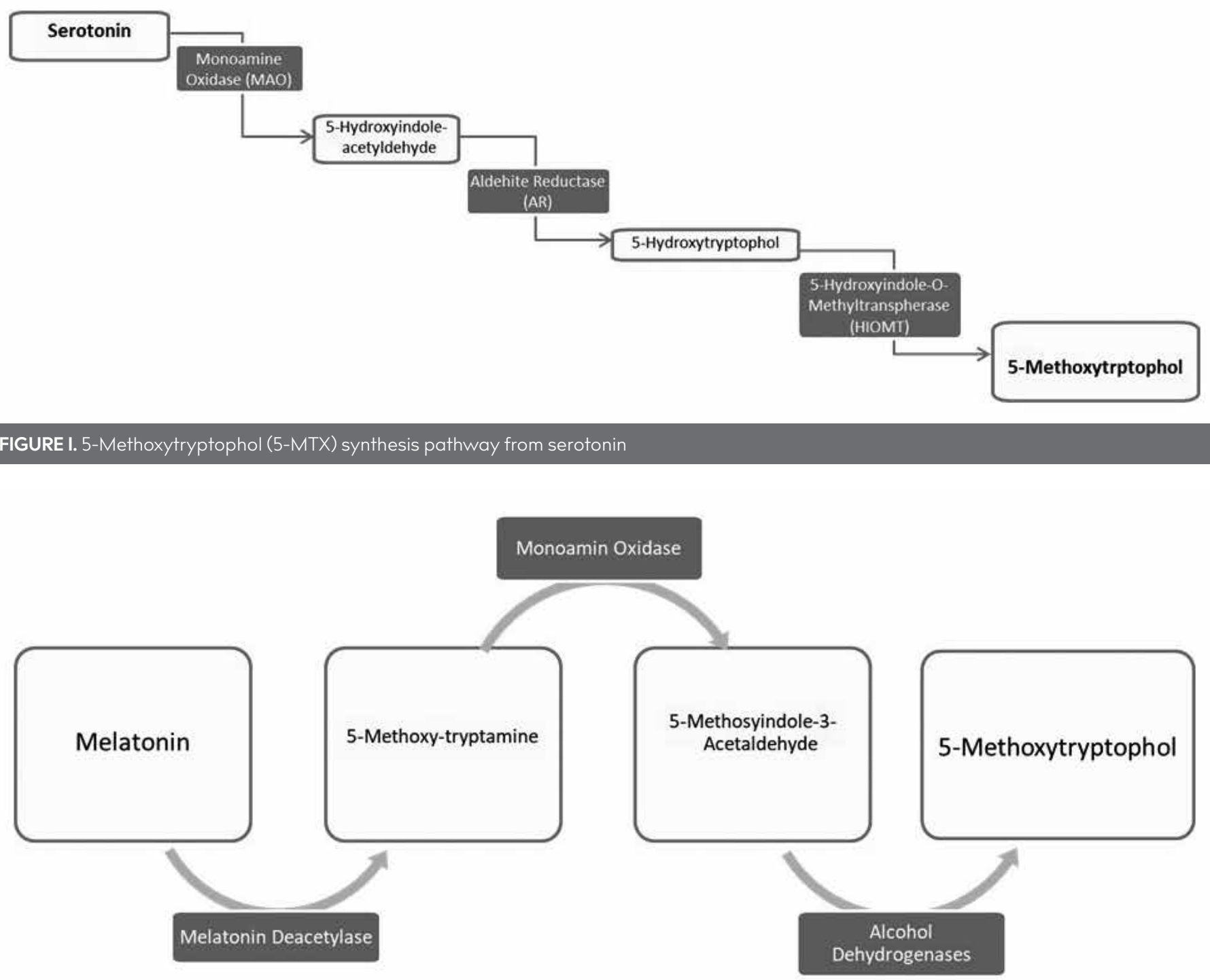

FIGURE 2. 5-Methoxytryptophol (5-MTX) synthesis pathway from melatonin

\section{Receptors}

In the receptor studies using radioligand 2-[I25I]-iodomelatonin, the $M T_{1}$ and $M T_{2}$ receptor affinity of MTX-5 in different species shows variance (5). The affinity is high in the receptors of chicken brains and retinas and rabbit retinas solely for the MT. $M T_{2}$ receptors have affinity in the hamster brain $(6,7)$. In humans, these two receptor subtypes are thought to be found intensely in the suprachiasmatic nucleus (SCN) and affect the entire biological system by spreading to other brain regions. MT, receptors are responsible for renal function, dermal function such as hair growth, sleep, circadian rhythm, and cerebral artery contractility (I). These receptors play a role in light-dependent events such as Ca-dependent dopamine release in mammalian retinas and phagocytosis of retinal photopigment discs (8). The $M T$, receptor activation causes $G$, adenylate cyclase inhibition via proteins. Also, only $M T$, receptors have been shown to stimulate arachidonate release via phospholipase activation. Low-affinity $\mathrm{MT}_{2}$ receptors are claimed to be closely connected with $G$ proteins and to behave in a similar way to $M T$, receptors. However, unlike $M T_{1}$ receptors, $\mathrm{MT}_{2}$ receptors have been indicated to cause phosphoinositide hydrolysis (9).
It has been found during studies that 5-MTX, just like melatonin, has the ability to enter many organelles. In particular, it can pass to the blood-brain barrier receptors. It can be found in high concentrations in the thyroid and adrenal glands, ovaries, and uterus cells, and it can be metabolized in urine as well (I). Although some studies have shown that there is a correlation between the concentration of 5-MTX in the pineal gland and serum levels, conflicting results arise. This is due to turnover, secretion, and the fact that the turnover to 5-MTX from 5-methoxyindoline does not follow a rhythmic course (I0). In addition, human organic anion transporter (hOAT) I and hOAT 3 of the solute carrier family carrier proteins efflux the 5-MTX from the cerebrospinal fluid to the choroid plexus, because of which this correlation does not occur. These carrier proteins play a facilitating role in the uptake of the drug into the cell, and they dynamically affect the accumulation of 5-MTX and its translocation in the cell (II).

\section{The Role in Physiological and Pathological Events}

5-MTX plays a part in physiological and neuroendocrine functions, although the cellular and molecular mechanisms of its release are still unknown. However, because it helps to remove free 
radicals and their antioxidant activity, it resembles melatonin (12). In particular, the studies of 5-MTX have shown that it increases superoxide dismutase and glutathione peroxidase levels and prevents lipid and protein oxidations, and thus has been caused by $\mathrm{FeCl} 3$ and ascorbic acid and has protective properties similar to melatonin $(13,14)$. In a study conducted in 1996 by Lissoni et al., it was found that 5-MTX reduced IL-6 levels, which are the immunostimulatory cytokines in serum, and increased the synthesis of immunosuppressive IL-2 and IL-I2. Since opposing circadian rhythms of melatonin and 5-MTX have been established, Lissoni suggest that these two indolamines, which act at different times of the day, should be used together to benefit from immunostimulatory effects (15). In a study by Savtekin and colleagues, it was also indicated that 5-MTX shows protective qualities by affecting matrix metalloproteinases 2 and 8 and TNF- $a$ and IL-I $\beta$ levels in zymosan-induced synovial inflammation (16).

It was also shown that by affecting human gingival fibroblasts, 5-MTX stimulates the healing of wounds in periodontal disease or dental implantology by reducing the expression of collagen III al, a decorin tissue inhibitor of metalloproteinases I, and IL-I0 (17). Potential use of this agent in the treatment of periodontal diseases is being considered due to its properties that increase the collagen synthesis and improve scar tissue healing, reduce the ROS levels, stimulate immunologic response, have antibacterial activity, and slow down the alveolar bone loss (18).

In addition to the antioxidant and immunomodulatory properties of 5-MTX, there are also hypothermic and hypotensive effects (19). In studies conducted on rats, it has been proposed that it shows an anxiolytic effect by the modulating of stress response (20). It is possible that its effects are the result of increased GABA-ergic activity, decreased metabotropic glutamatergic activity, and modulation of the opioidergic system just like melatonin does. Alongside melatonin, it is present in the regulation of the sleep cycle (2I). In vitro studies conducted on hormones have indicated that 5-MTX increases the osteoblastic activity and inhibits the osteoclastic activity in bone cells. According to this study, 5-MTX was found to stimulate the osteoblast differentiation more than melatonin, clearly showing an increased secretion of osteocalcin (22). It has been suggested that by blocking the nicotinic and muscarinic acetylcholine receptors, 5-MTX inhibits the FSH and LH, the anterior pituitary hormones, and has antigonadotropic effects by affecting the gonads. In toxicological studies performed, fetotoxic and teratogenic effects were observed even at normal doses $(23,24)$.

\section{CONCLUSION}

In all these findings, it is understood that 5-MTX released in the light with the hormone melanin released in the dark has a 24hour protective effect on the body. Therefore, in studies concerning melatonin, the application of 5-MTX alongside it, as it imitates the daytime rhythm, will lay a foundation for alternative treatment regimens to emerge as it brings a new perspective, causing new clinical, scientific studies to arise.

Peer-review: Externally peer-reviewed.

Author Contributions: Concept - A.Ö.Ș, G.S.; Design A.Ö.Ș, G.S.; Supervision - A.Ö.Ș.; Resource - A.Ö.Ș, G.S.; Materials A.Ö.Ș, G.S.; Data Collection and/or Processing - A.Ö.Ș., G.S.; Analysis and/or Interpretation - A.Ö.Ș., G.S.; Literature Search A.Ö.Ș., G.S.; Writing - A.Ö.Ș.; Critical Reviews - A.Ö.Ș.
Conflict of Interest: The authors have no conflicts of interest to declare.

Financial Disclosure: The authors declared that this study has received no financial support.

\section{REFERENCES}

I. Ouzir M, Bouhaddou N, Khalki H, Lakhdar-Ghazal N. Physiological and pharmacological properties of 5-methoxytryptophol. Expert Rev Endocrinol Metab 2013; 8: 355-64. [CrossRef]

2. Hofman MA, Skene DJ, Swaab DF. Effect of photoperiod on the diurnal melatonin and 5-methoxytryptophol rhythms in the human pineal gland. Brain Res 1995; 671: 254-60. [CrossRef]

3. Balemans MG, Pévet P, Legerstee WC, Nevo E. Preliminary investigations of melatonin and 5-methoxy-tryptophol synthesis in the pineal, retina, and harderian gland of the mole rat and in the pineal of the mouse "eyeless". J Neural Transm 1980; 49: 247-55. [CrossRef]

4. Grace MS, Cahill GM, Besharse JC.Melatonin deacetylation: retinal vertebrate class distribution and Xenopus laevis tissue distribution. Brain Res 1991; 559: 56-63. [CrossRef]

5. Yau MY, Pang CS, Kravtsov G, Pang SF, Shiu SY. 2[I25I] lodomelatonin binding sites in guinea pig platelets. J Pineal Res 2002; 32: 97105. [CrossRef]

6. Duncan MJ, Takahashi JS, Dubocovich ML. Characterization and localization of 2-[1251]-iodomelatonin binding sites in Diungarian hamster brain. Endocrinology 1989; 125: I0II-8. [CrossRef]

7. Yuan H, Tang F, Pang SF. Binding characteristics, regional distribution and diurnal variation of [1251]-iodomelatonin binding sites in the chicken brain. J Pineal Res 1990; 9: 179-91. [CrossRef]

8. Lewczuk B, Ziółkowska N, Prusik M, Przybylska-Gornowicz B. Diurnal profiles of melatonin synthesis-related indoles, catecholamines and their metabolites in the duck pineal organ. Int J Mol Sci 20I4; 15: 12604-30. [CrossRef]

9. Dubocovich ML, Markowska M. Functional MTI and MT2 melatonin receptors in mammals. Endocrine 2005; 27: I0I-I0. [CrossRef]

10. ReppertSM. Melatonin receptors: molecular biology of a new family of $G$ protein-coupled receptors. J Biol Rhythms 1997; 12: 528-31. [CrossRef]

II. Alebouyeh M, Takeda M, Onozato ML, Tojo A, Noshiro R, Hasannejad $\mathrm{H}$, et al. Expression of human organic anion transporters in the choroid plexus and their interactions with neurotransmitter metabolites. J Pharmacol Sci 2003; 93: 430-6. [CrossRef]

12. Millán-Plano S, Piedrafita E, Miana-Mena FJ, Fuentes-Broto L, Martínez-Ballarín E, López-Pingarrón L, et al. Melatonin and structurally-related compounds protect synaptosomal membranes from free radical damage. Int J Mol Sci 20I0; II: 312-28. [CrossRef]

13. Poeggeler B, Reiter RJ, Hardeland R, Tan DX, Barlow-Walden LR. Melatonin and structurally-related, endogenous indoles act as potent electron donors and radical scavengers in vitro. Redox Rep 1996; 2: 179-84. [CrossRef]

14. Wang HX, Liu F, Ng TB. Examination of pineal indoles and 6-methoxy-2-benzoxazolinone for antioxidant and antimicrobial effects. Comp Biochem Physiol C Toxicol Pharmacol 2001; 130: 379-88. [CrossRef]

15. Lissoni P. Modulation of anticancer cytokines IL-2 and IL-I2 by melatonin and the other pineal indoles 5-methoxytryptamine and 5 -methoxytryptophol in the treatment of human neoplasms. Ann N Y Acad Sci. 2000; 917: 560-7. [CrossRef]

16. Savtekin G, Tuzum MS, Uyanik LO, Ayali A, Velioglu Ogunc A, Cetinel $S$, et al. Effects of melatonin and 5-methoxytryptophol on synovial inflammation in the zymosan-induced rheumatoid arthritis in rats. Int J Clin Exp Med 2016; 9: 7137-44.

17. Gómez-Florit M, Ramis JM, Monjo M. Anti-fibrotic and anti-inflammatory properties of melatonin on human gingival fibroblasts in vitro. Biochem Pharmacol 2013; 86: 1784-90. [CrossRef]

18. Satué $M$, Ramis JM, del Mar Arriero $M$, Monjo $M$. A new role for 5 -methoxytryptophol on bone cells function in vitro. J Cell Biochem 2015; |l6: 55I-8. [CrossRef] 
19. Wang $\mathrm{H}, \mathrm{Ng}$ TB. Hypotensive activity of the pineal indoleamine hormones melatonin, 5-methoxytryptophol and 5-methoxytryptamine. Pharmacol Toxicol 2000; 86: 125-8. [CrossRef]

20. Naranjo-Rodriguez EB, Osornio AO, Hernandez-Avitia E, Mendoza-Fernández $V$, Escobar A. Anxiolytic-like actions of melatonin, 5-metoxytryptophol, 5-hydroxytryptophol and benzodiazepines on a conflict procedure. Prog Neuropsychopharmacol Biol Psychiatry 2000; 24: I17-29. [CrossRef]

21. Zawilska JB, Berezińska M, Rosiak J, Vivien-Roels B, Skene DJ, Pévet $P$, et al. Daily variation in the concentration of melatonin and 5-methoxytryptophol in the goose pineal gland, retina, and plasma. Gen Comp Endocrinol 2003; 134: 296-302. [CrossRef]
22. Sewerynek E, Wiktorska JA, Stuss M. 6-methoxytryptophol reduces lipopolysaccharide-induced lipid peroxidation in vitro more effectively than melatonin. J Physiol Pharmacol 2011; 62: 677-83.

23. Yáñez J, Meissl H. Secretion of the methoxyindoles melatonin, 5-methoxytryptophol, 5-methoxyindoleacetic acid, and 5-methoxytryptamine from trout pineal organs in superfusion culture: effects of light intensity. Gen Comp Endocrinol 1996; 101: 165-72. [CrossRef]

24. Molina-Carballo A, Mu-oz-Hoyos A, Martin-García JA, Uberos-Fernández J, Rodriguez-Cabezas T, Acu-a-Castroviejo D. 5-Methoxytryptophol and melatonin in children: differences due to age and sex. J Pineal Res 1996; 21: 73-9.[CrossRef] 